UTILITY: Jurnal Ilmiah Pendidikan dan Ekonomi

Volume 5, No. 1, Februari 2021: Page 1-9

ISSN 2549-1377 (Print) || ISSN 2549-1385 (Online)

Available online at http://journal.stkipnurulhuda.ac.id/index.php/utility

\title{
KEPEMIMPINAN KEPALA SEKOLAH YANG EFEKTIF DI SMAN NEGERI KOTA PALEMBANG
}

\author{
M Bambang Purwanto ${ }^{1}$ \\ ${ }^{1}$ Politeknik Darussalam \\ *E-mail: mbambangpurwanto@gmail.com
}

\begin{abstract}
Abstrak: Penelitian ini bertujuan untuk mengetahui keefektifan kepemimpinan kepala sekolah. Metode pengumpulan data yang dipergunakan adalah kuesioner atau angket. Analisis data kuantitatif dengan menggunakan analisis deskriptif. Populasi berjumlah 12 orang, sampel penelitian berjumlah 12 orang. Subyek dalam penelitian ini yaitu kepala sekolah seluruh SMA Negeri se-Kabupaten Lumajang. Berdasarkan hasil analisis yang diperoleh melalui penyebaran angket atau kuesioner pada 12 responden yaitu kepala sekolah SMAN seKabupaten Lumajang diperoleh data secara keseluruhan tentang kepemimpinan kepala sekolah yang efektif. Terdiri dari 35 pernyataan dan 5 alternatif jawaban, menunjukkan bahwa data tentang tingkat kualitas kepemimpinan kepala sekolah yang efektif secara umum berada pada katagori baik. Hasil penelitian ini menunjukkan bahwa tingkat kualitas kepemimpinan kepala sekolah yang efektif dapat dikualifikasikan baik dengan 9 responden atau $75 \%$.
\end{abstract}

Kata Kunci: Kepala sekolah, Kepemimpinan

\section{PENDAHULUAN}

Salah satu permasalahan pendidikan yang dihadapi oleh bangsa Indonesia adalah rendahnya mutu pendidikan pada setiap jenjang dan satuan pendidikan. Berbagai usaha telah dilakukan untuk pengembangan kurikulum nasional dan lokal, meningkatkan mutu pendidikan nasional, misalnya pengadaan buku dan alat pelajaran, pengadaan dan perbaikan sarana dan prasarana pendidikan, serta peningkatan mutu manajemen sekolah dengan cara meningkatkan kualitas kepala sekolah(Abdullah, 2018: 190) .

Kemudian salah satu aspek kepemimpinan di dunia pendidikan adalah kepemimpinan di suatu sekolah. Sekolah sebagai unit kerja dipimpin oleh seorang kepala sekolah. Tak luput sorotan tentang kepala sekolahpun mulai tajam. Untuk dapat bersaing di era globalisasi, maka diperlukan kepala sekolah-kepala sekolah yang profesional. Kepala sekolah yang profesioa nl tak ter lepas dari paradigma kepemimpinan pada umumnya. Kepemimpinan itu sendiri diterjemahkan ke dalam istilah sifat-sifat, perilaku pribadi, pengaruh terhadap orang lain, pola-pola interaksi, hubungan kerja sama antar peran, kedudukan dari satu jawaban administratif, dan persepsi dari lain-lain tentang legitimasi pengaruh. 
Pemimpin a dalah seorang yang karena kecakapan-kecakapan pribadinya dengan atau tanpa pengangkatan resmi dapat mempengaruhi kelompok yang dipimpinnya untuk mengerahkan tersebut pengertian pemimpin mewujudkan adanya tujuan bersama (Winardi, 2004:304). Dari pendapat usaha bersama ke arah pencapaian sasaran atau orang lain. Jadi bila ditarik kesimpulan dari pendapat di atas, pemimpin adalah orang yang memimpin dan memberi kegairahan kerja terhadap kemampuan untuk menggerakkan, membimbing dapat mempengaruhi, menggerakkan, menumbuh kan perasaan ikut serta dan tanggung jawab, memberikan fasilitas, tauladan yang baik serta kegairahan kerja terhadap orang lain. Namun banyak faktor penghambat tercapainya kualitas keprofesionalan kepemimpinan kepala sekolah seperti proses pengangkatannya tidak transparan, rendahnya mental kepala sekolah yang ditandai dengan kurangnya motivasi dan semangat serta kurangnya disiplin dalam melakukan tugas, dan seringnya datang terlambat, wawasan kepala sekolah yang masih sempit, serta banyak faktor penghambat lainnya yang menghambat tumbuhnya kepala sekolah yang profess ional untuk meningkatkan kualitas pendidikan. Ini mengimplikasikan rendahnya produktivitas kerja kepala sekolah yang berimplikasi juga pada mutu (input, proses, dan output).

Kepala sekolah merupakan salah satu kekuatan efektif dalam pengelolaan sekolah yang berperan bertanggung jawab dalam menghadapi perubahan aga $r$ para guru, staf dan siswa menyadari akan tujuan sekolah yang tela $h$ ditetapkan, dengan kesadaran tersebut para guru, staf dan siswa dengan penuh semangat melaksanakan tugas masing-masing dalam mencapai tujuan sekolah (Iskandar; 2013:10). Menurut Wahjosumidjo (2007) kepala sekolah merupakan dua gabungan kata, kedua kata terebut adalah "kepala" dan "sekolah". Kata kepala dapat diartikan "ketua" atau "pemimpin" dalam suatu organisasi atau sebuah lembaga. Sedangkan "sekolah" adalah sebuah lembaga dimana menjadi tempat menerima dan memberi pelajaran.

Dari definisi di atas dapat menarik kesimpulan ba hwa kepala sekolah ada lah seorang yang ditunjuk sebagai pemimpin di satuan pendidikan. Pemimpin ada dua macam, yaitu pemimpin formal dan pemimpin nonformal. Pemimpin formal, artinya dia diangkat secara formal (formally designated leader) oleh organisasi yang bersangkutan atau organisasi yang menjadi atasannya. Sehingga secara organisatoris mempunyai tugas membina, membimbing, memberi bantuan dan dorongan kepada staf sekolah untuk mencapai tujuan yang ingin dicapai. Siapapun yang akan diangkat menjadi kepala sekolah harus ditentukan melalui prosedur serta persyaratan-persyaratan tertentu.

Kepemimpinan diterjemahkan kedalam istilah sifat-sifat, perilaku pribadi, pengaruh terhadap orang lain, pola-pola interaksi, hubungan kerja sama antar peran, kedudukan dari suatu jabatan administratif, dan persepsi lain tentang legitimasi pengaruh (Wahyosumidjo:2007). Dapat disimpulkan bahwa pengertian kepemimpinan adalah suatu kegiatan dalam membimbing suatu kelompok sedemikian rupa sehingga tercapailah tujuan kelompok itu. Tujuan tersebut 


\section{KEPEMIMPINAN KEPALA SEKOLAH YANG EFEKTIF DI SMAN NEGERI KOTA PALEMBANG}

merupaka tujuan bersama. Dalam usaha untuk mencapai tujuan berama itu, pemimpin dan kelompok yang satu bergantung pada kelompok dan pemimpin yang la in. S es eor ang tidak dapat menj a di pemimpin terlepas dari kelompok. Kepemimpinan merupakan suatu sifat dari kelompok. Setiap orang sebagi anggota suatu kelompok dapat memberikan sumbangannya untuk kesuksesan kelompoknya.

Indra fachrud i (2006) menyatakan kepemimpinan adalah suatu kegiatan dalam membimbing suatu kelompok sedemikian rupa sehingga tercapailah tujuan kelompok itu. Tujuan tersebut merupakan tujuan bersama. Kepemim- pinan dapat didefinisikan sebagai kategori perilaku ya ng dapat membuat seseor ang (pemimpin) mampu mempengaruhi orang lain (Hanurawan,2002:34). Mengingat tugas kepemimpinan yang kompleks, pengertian kepemimpinan tidak dapat diba tasi secar a pasti, termasuk pengertia n kepemimpinan efektif di sekolah. Namun, sejumlah rujukan menjelaskan bahwa kepemimpinan efektif di sekolah dapat berkait dengan kepemimpinan kepala sekolah di sekolah yang efektif. Atas dasar pandangan ini, maka kepemimpinan efektif di sekolah dapat dimengerti sebagai bentuk kepemimpinan yang menekankan kepada pencapaian prestasi akademik dan non akademik sekolah.

Sebagai pemimpin pendidikan di sekolah, kepala sekolah memiliki tanggungjawab legal untuk mengembangkan staf, kurikulum, dan pelaksanaan pendidikan di sekolahnya. Efektifitas kepemimpin- an kepala sekolah tergantung kepada kemampuan bekerjas a ma dengan guru dan staf, serta kemampuannya mengendalika $n$ pengelolaa $n$ anggaran, pengembangan staf, scheduling, pengembangan kuriku lu $\mathrm{m}$, paedagogi, da $\mathrm{n}$ assessmen. Membekali kepala sekolah memiliki seperangkat kemampuan ini dirasa sangat penting. Indrafacrudi (2006: 3), pada dasarnya dapat fungsi kepemimpinan pendidik dibagi atas dua macam, yaitu: a) fungsi yang bertalian dengan tujuan yang hendak dicapai, b) fungsi yang bertalian dengan penciptaan suasana pekerjaan yang sehat dan menyenangkan sambil memeliharanya. Hasil penyelidikan Tead (dalam Indrafachrudi, 2006) diangga $p$ penting seka li bagi kepemimpinan pendidikan. la menyarankan sifat kepemimpinan pendidikan sebagai berikut: (a) memiliki kesehatan jasmaniah dan rohaniah yang baik, (b) berpegang teguh pada tujuan yang hendak dicapai, (c) bersemangat, (d) jujur, (e) cakap dalam memberi bimbinga $n$, (f) cep at ser ta bijaksa na dalam mengambil keputusan, (g) cerdas, dan (h) cakap dalam hal mengajar dan menaruh kepercayaan pada yang baik dan berusaha mencapainya.

Cara-cara seorang pemimpin melaksanakan kepemimpinannya berbeda-beda. Berdasarkan konsep official leadership, dapat dibedakan empat tipe kepemimpinan, yaitu: (a) kepemimpinan otokratis, (b) kepemimpinan pseudodemokratis, (c) kepemimpinan laisses-faire, (d) kepemimpinan demokratis (Indrafachrudi, 2006). Kepala sekolah dalam melaksanakan kepemimpinan hendaklah menggunakan pengetahuan, pengalaman, dan sifat kepemimpinan. Sehubungan dengan itu, kepala sekolah dituntut memiliki kemahiran dan keterampilan dalam mengelola lembaga pendidikan (Indrafachrudi, 2006). Ada 
beberapa macam keterampilan, yaitu: (1) keterampilan memimpin, (2) keterampilan menjalin hubungan kerja sama denga $n$ ses ama manusia, (3) ket erampila $n$ menguasai kelompok, (4) keterampilan mengelola administrasi personalia, (5) keterampilan menilai.

Tiap-tiap teori dan definisi di atas sinkron denga $n$ pendek a ta $n-p$ en deka ta $n$ yang diusahakannya. Pendekatan-pendekatan itu adalah untuk memecahkan mas alah-mas alah kepemimpinan yang telah lama dilakukan dan diselidiki oleh para ahli (Indrafachrudi, 2006). Pada dasarnya, ada 2 macam pendekatan dalam kepemimpinannya, yaitu: (1) pendekatan sifat-sifat, (2) pendekatan sifat.

Betapa perlunya kualitas kepemimpinan kepala sekolah, maka selalu ditekankan pentingnya tiga kemampuan dasar yang perlu dimiliki oleh kepala sekolah, yaitu conceptual skills, human skills, technical skills. Dengan memiliki tiga macam keterampilan dasar tersebut, kepala sekolah diharapkan mampu dalam hal: a) menentukan tujuan sekolah, b) mengorganisa sikan atau mengatur sekolah, c) menanamkan pengaruh atau kewibawaan kepemimpinannya, d) memperbaiki pengambilan keputusan, dan e) melaksanakan perubahan (perbaikan) pendidikan.

\section{METODE}

Jenis penelitian ini adalah jenis penelitian deskriptif. Metode penelitian deskriptif digunakan untuk mendapatkan informasi tentang suatu gejala pada saat penelitian dilakukan. Penelitian deskriptif menghasilkan hasil penelitian yang tarafnya dalam memberikan penjelasan mengenai masalah yang diteliti. Dengan demikian dapat disimpulkan, bahwa penelitian ini adalah penelitian deskriptif. Karena penelitian menggunakan perhitungan angka (bilangan) terhadap data yang diperoleh untuk pengujian hipotesis.

Arikunto (1996:115) mendifinisikan "populasi adalah keseluruhan subyek penelitian". Berdasarkan definisi tersebut, sesuai dengan judul penelitian ini yang menjadi populasi dalam penelitian ini adalah semua kepala SMAN Kota Palembang. Ber das arkan definisi tersebut, sesuai dengan judul penelitian ini maka yang menjadi populasi dalam penelitian ini adalah semua kepala SM AN Kota Palembang. Jumlah populasi yang ditetapkan sebagai objek penelitian adalah sebanyak 12 kepala sekolah menengah atas negeri. Sampel penelitian menurut Arikunto (1993:104) adalah "sebagian atau wakil populasi yang diteliti". Sementara Hadi (1987:221) mengartikan sampel sebagai "sejumlah penduduk yang jumlahnya kurang dari populasi". Penentuan bes arnya sampel masih belum didapatkan kesepakatan yang jelas, besarnya sampel yang harus diambil agar diperoleh sampel yang representatif. Hal ini sesuai pendapat yang mutlak berapa persen suatu sampel harus diambil dari populasi. Dalam penelitian ini sampelnya adalah seluruh kepala SMAN Kota Palembang.

Berdasarkan pendapat di atas, penelitian mengambil semua kepala sekolah sebagai sampel yang berjumlah 12 orang. Menurut Arikunto (2006:160) mengemukakan bahwa instrumen penelitian adalah alat atau fasilitras ya 


\section{KEPEMIMPINAN KEPALA SEKOLAH YANG EFEKTIF DI SMAN NEGERI KOTA PALEMBANG}

ng digunakan oleh peneliti dalam mengumpulkan data agar pekerjaannya lebih mudah dan hasilnya lebih baik, da lam arti lebih cermat, lengkap, dan sistematis sehingga lebih mudah diolah. Instrumen yang diguna kan dalam penelitian ini adalah angket. Angket merupakan suatu cara pengumpulan data dengan menyebarkan sejumlah pertanyaan atau pernyataan. Angket atau kuesioner menurut Arikunto (1996: 139) adalah "sejumlah pertanyaan yang digunakan untuk memperoleh informasi dari responden dalam arti laporan tentang pribadinya atau hal hal lain yang ia ketahui".

\section{HASIL DAN PEMBAHASAN}

\section{Hasil}

\section{Kepemimpinan Kepala Sekolah yang Effektif}

Berdasarkan angket yang telah disebar kepada kepala sekolah SMAN se-Kabupaten Lumajang diperoleh data keseluruhan tentang kepemimpinan kepala sekolah yang efektif. Terdiri dari 35 pernyataan dan 5 alternatif jawaban. Berdasar kan dari seluruh data mengenai kepemimpinan kepala sekolah yang efektif sebanyak 9 responden atau 75\% tergolong kategori baik, sedangkan yang tergolong cukup sebanyak 3 responden atau $25 \%$, pada kualifikasi rendah sebanyak 0 responden ata u $0 \%$. Jadi dap at disimpulkan bahwa kepemimpinan kepala sekolah yang efektif tergolong baik.

\section{Fungsi Kepemimpinan Kepala Sekolah Menengah Atas}

Deskripsi data tentang syarat kepemimpinan kepala sekolah pada penelitian ini dibuat angket yang terdiri dari 10 item pernyataan yang kemudian diukur dengan skor 1 sampai 5, dengan angket disebarkan kepada responden sebanyak 12 orang kepala sekolah yang menjadi responden dalam penelitian. Dapat diketahui dari 12 responden, jumlah responden ya ng a da pada ku alifika si tinggi sebanyak 9 responden atau $75,00 \%$, pada kualifikasi sedang sebanyak 3 responden atau $25,00 \%$, pada kualifikasi rendah sebanyak 0 responden atau $0,00 \%$.

\section{Syarat Kepemimpinan Kepala Sekolah Menengah Atas}

Deskripsi data tentang tipe-tipe kepemimpinan kepala sekolah pada penelitian ini dibuat angket yang terdiri dari 4 item pernyataan yang kemudian diukur dengan skor 1 sampai 5 , dengan angket disebarkan kepada responden sebanyak 12 orang kepala sekolah yang menjadi responden dalam penelitian. Dapat diketahui dari 12 responden, jumlah responden yang ada pada kualifikasi tinggi sebanyak 0 responden atau $0,00 \%$, pada kualifikasi sedang sebanyak 10 responden atau $83,33 \%$, pada kualifikasi rendah sebanyak 2 responden atau $16,67 \%$

\section{Keterampilan Kepemimpinan Kepala Sekolah Menengah Atas}


Deskripsi data tentang keterampilan kepemimpinan kepala sekolah pada penelitian ini dibuat angket yang terdiri dari 13 item pernyataan yang kemudian diukur dengan skor 1 sampai 5 , dengan angket disebarkan kepada responden sebanyak 12 orang kepala sekolah yang menjadi responden dalam penelitian. Diket a hu i dari 12 responden, ju mla h responden yang ada pada kualifikasi baik sebanyak 3 responden atau 25,00\%, pada kualifikasi cukup sebanyak 9 responden atau $75,00 \%$, pada kualifikasi rendah sebanyak 0 responden atau $0,00 \%$.

\section{Pembahasan}

\section{Kepemimpinan Kepala Sekolah yang Efektif}

Berdasarkan hasil analisis yang diperoleh melalui penyebaran angket atau kuesioner pada 12 responden yaitu kepala sekolah SMAN Kota Palembang dip eroleh data secara keseluruhan tentang kepemimpinn kepala sekolah yang efektif yaitu pada kategori baik. Dengan demikian, pemimpin pendidikan efektif selalu berkonsentrasi untuk menggerakkan faktor-faktor potensial bagi ketercapaian tujuan sekolah. Sebagai pemimpin pendidikan pula, kepala sekolah efektif mampu menunju kka n k ema mp u a nnya mengembangkan potensi-potensi sekolah, guru, dan siswa untuk mencapai prestasi maksimal. dapat ditegaskan bahwa kepemimpinan efektif adalah kepemimpinan kepala sekolah yang memfokus kepada pengembangan ins t ruks io nal, organisasional, staf, layanan murid, serta hubungan dan komunikasi dengan masyarakat. Sajian materi ini akan mendeskripsikan kepemimpinan efektif kepala sekolah, ditinjau dari aktifitasnya dalam berkomunikasi, membangun teamwork, mengambil keputusan, menangani konflik, dan memelihara budaya kerja di sekolah.

\section{Fungsi Kepemimpinan Kepala Sekolah}

Berdasarkan hasil analisis yang diperoleh melalui penyebaran angket atau kuesioner pada 12 responden yaitu kepala sekolah SMAN Kota Palembang, menunjukkan bahwa data tentang fungsi kepala sekolah secara umum berada pada katagori baik. Fungsi kepala sekolah ini telah memenuhi kriteria pada teori yaitu terdapat beberapa fungsi kepemimpinan: pertama, agar organisasi dapat berjalan secara efektif maka harus ada semua faktor (dalam hal ini adalah kepemimpinan) sehingga perilaku individu dapat diarahkan pada orientasi penyelesaian tugas. Kedua, kepemimpinan dapat membantu stabilitas suatu organisasi dalam lingkungan yang selalu berubah dengan melakukan penyesuaian dan adaptasi untuk merubah kondisi-kondisi lingkungan. Ketiga, dalam konteks dinamika organisasi, kep emimpinan da $\mathrm{p}$ at memba ntu melaku ka $\mathrm{n}$ koordinasi diantara unit-unit organisasi yang berbeda-beda terutama dalam masa pertumbuhan dan perubahan. Keempat, kepemimpinan memiliki peran penting dalam memelihara kestabilan gugus kerja dengan memfasilitasi kebutuhan dan pencapaian tujuan personal, menurut Katz dan Kahn (dalam Hanurawan, 2002:34).

\section{Syarat Kepemimpinan Kepala Sekolah}




\section{KEPEMIMPINAN KEPALA SEKOLAH YANG EFEKTIF DI SMAN NEGERI KOTA PALEMBANG}

Berdasarkan hasil analisis yang diperoleh melalui penyebaran angket atau kuesioner pada 12 responden yaitu kepala sekolah SMAN Kota Palembang, menunjukkan bahwa data tentang syarat pemimpin pendidikan berada pada kategori tinggi. Kepala sekolah, sebagai pemimpin harus mengakui bahwa bekerja sama berarti bahwa masinngmasing harus memberi sumbangan yang sebaik mungkin sesuai dengan kesanggupan dalam melaksanakan rencana pendidikan di sekolah. Agar pelaksanaan tugas dan pekerjaanya berjalan lancar, seorang pemimpin harumemiliki sifat seperti mau berinisiatif, percaya diri, setia, tekun, dan jujur. Kepercayaan akan terwujud apabila kita memiliki dan menunjukan sifat seperti ikhlas, tulus hati, dan terus terang. Alangkah baiknya apabila syarat-syarat kepemimpinan tersebut ditunjang juga oleh keahlian dalam profesinya, yang mencakup penguasaan penget ahuan, terutama dalam bidangnya, pengalaman, dan keterampilan yang dimilikinya.

\section{Tipe-Tipe Kepemimpinan Kepala Sekolah}

Berdasarkan hasil analisis yang diperoleh melalui penyebaran angket atau kuesioner pada 12 responden yang disini kepala sekolah SMAN Kota Palembang, menunjukkan bahwa data tentang tipe-tipe kepemimpinan pendidikan secara umum berada pada katagori tinggi. Tipe- tipe kepemimpinan yang diuraikan adalah tipe-tipe yang sangat berkaitan dengan sifat dan watak pribadi seorang pemimpin. Di dalam praktik ternyata tipe-tipe itu bervariasi tergantung pada situasi kematangan bawahan (terpimpin) yang dibinanya.

\section{Keterampilan Kepemimpinan Kepala Sekolah}

Berdasarkan hasil analisis yang diperoleh melalui penyebaran angket atau kuesioner pada 12 responden yang disini kepala sekolah SMAN se-Kabupaten Lumajang, menunjukkan bahwa data tentang syarat pemimpin pendidikan berada pada katagori sangat cukup. Ada beberapa macam keterampilan menurut Indrafachrudi (2006), antara lain sebagai berikut: (a) keterampilan Memimpin, (b) keterampilan Menjalin Hubungan Kerja dengan Sesama Manusia, (c) keterampilan Menguasai Kelompok, (d) Keterampilan Mengelola Administrasi Pesonalia, (e) Keterampilan Menilai. Berdasarkan teori diatas, kepala sekolah telah memenuhi semua keterampilan yang disebutkan diatas.

\section{SIMPULAN}

Kepemimpinan Kepala Sekolah yang Efektif secara keseluruhan dinilai dalam kategori baik. Jadi keseluruhan kepala sekolah telah memenuhi segala kriteria yang ada. Fungsi kepala sekolah SMAN Kota Palembang. secara keseluruhan sudah baik, dengan segala perhitungan dan analisis yang dilakukan oleh peneliti dapat disimpulkan adalah baik. Syarat kepemimpinan kepala sekolah dalam penelitian ini secara keseluruhan cukup. Semua kepala sekolah sudah memenuhi syarat pemimpin pendidikan ini. Tipe-tipe kepemimpinan kepala sekolah secara umum berada pada katagori sedang. Hasil penelitian ini menunjukkan bahwa tingkat kualitas tipe-tipe 
kepemimpinan kepala sekolah dapat dikualifikasikan sedang. Keterampilan kepemimpinan kepala sekolah hasil penelitian ini menunjukkan bahwa syarat pemimpin pendidikan dikualifikasikan cukup.

Sebagai acuan untuk menjadi lebih baik, menambah wawasan dan pengetahuan. Dapat digunakan sebagai bahan pertimbangan atau acuan dalam mengembangkan pola pengelolaan program sekolah. Dan untuk lebih meningkatkan fungsi, tipe dan keterampilan kepemimpinan kepala sekolah menengah atas di Kota Palembang. Sebagai bahan wacana bagi guru, untuk meningkatkan profesionalisme guru untuk melangkah lebih baik lagi. Sebagai bahan pembanding dan penambah referensi demi pengembangan ilmu, terutama sumber daya manusia. Sebagai bahan pengetahuan bekal dan keterampilan di kemudian hari, serta dapat dijadikan bahan referensi dan memberi wawasan yang banyak tentang kepemimpinan kepala sekolah yang efektif.

\section{UCAPAN TERIMAKASIH}

Ucapan terimakasih kepada kedua orang tuaku dan Istri serta anak-anak anak ku yang tercinta.

\section{REFERENSI}

Abdullah, M. (2018). Manajemen Mutu Pendidikan di Sekolah Peran Kepemimpinan Kepala Sekolah, Profesionalisme Guru, dan Partisipasi Masyarakat Dalam Peningkatan Mutu Pendidikan di Sekolah. Jurnal Penelitian Pendidikan, 17(3), 190-198.

Ali, M. 1987. Penelitian Kependidikan Prosedur dan Strategi. Bandung: Angkasa.

Arikunto, S. 2006. Prosedur Penelitian Suatu Pendekatan Praktek. Jakarta: PT. Rineka Cipta.

Bungin, B. 2008. Metodologi Penelitian Kuantitatif: Komunikasi, Ekonomi, dan Kebijakan Publik serta IImi-IImu Sosial Lainnya. Jakarta: Kencana Prenada Media Group.

Hadi, S. 1987. Statistik II. Yogyakarta: YPFP UGM.

Hanurawan, F. 2002. Psikologi Sosial Terapan. Malang: Triumvat Press.

Indrafachrudi, S. 2006. Bagaimana Memimpin Sekolah yang Efektif. Bogor: Ghalia Indonesia.

Iskandar, U. (2013). Kepemimpinan kepala sekolah dalam peningkatan kinerja guru. Jurnal visi ilmu pendidikan, 10(1).

Riduwan. 2005. Skala Pengukuran Variabel- Variabel Penelitian. Bandung: Alfabeta. 


\section{KEPEMIMPINAN KEPALA SEKOLAH YANG EFEKTIF DI SMAN NEGERI KOTA PALEMBANG}

Sugiono. 2010. Metode Penelitian Pendidikan. Bandung: Alfabeta.

Umar, H. 2004. Metode Penelitian untuk Skripsi dan Tesis Bisnis. Jakarta: PT. Raja Grafindo Persada.

Wahyosumidjo. 2007. Kepemimpinan Kepala Sekolah. Jakarta: PT Raja Gr afindo Persada.

Winardi, J. 2004. Manajemen Perilaku Organisasi. Jakarta: Prenada Media. 